\title{
DEVELOPMENT AND PSYCHOMETRIC PROPERTIES OF NEGORI (NEGATIVE ORIENTATION QUESTIONNAIRE)
}

\begin{abstract}
There are several available questionnaires, which measure negative problem orientation with one factor. Our aim was to create such a multi-factor questionnaire that enables a more detailed and reliable analysis of interpersonal problems and one's negative orientation towards their solutions in adolescence. We carried out two data collections during the development of the questionnaire $\left(\mathrm{N}_{2016}=952, \mathrm{~N}_{2017}=835\right)$ among 12-, 15- and 18-year-olds. The tested statements were chosen based on the category system of an earlier pilot research as well as students' and professionals' statements which were then organised into a factor structure. To analyse convergent and discriminative validity, SPSI-R (D’Zurilla et al., 2002) was used. The EFA and CFA greatly support the theoretical factor structure, and the SEM also confirmed what had been thought about the system of connections of the latent dimensions. The result of the questionnaire development is the 21-item, 6-factor NEGORI (Negative Orientation Questionnaire) which bears quite good reliability indexes in all age groups and which can measure the following aspects within negative orientation: negative self-efficacy; negative consequences; positive consequences; habits, pattern; waiting; fending off the problem. We gained different and more detailed information as compared to previous data related to age and gender.
\end{abstract}




\section{Introduction: The characteristics and measurement of negative problem orientation}

The success of social problem-solving largely depends on one's problem orientation in general and the given problem, problem-solving as a process and how effective problemsolvers we regard ourselves (e.g., D'Zurilla et al., 2002; Frauenknecht \& Black, 2010; Strough \& Keener, 2013). National and international research (e.g., Eskin, 2013; Kasik, 2015) both show that if one's orientation is negative, for example he/she believes that the given problem is unsolvable and he/she thinks that nothing can be done for a solution and the likelihood of unsuccessful problem-solving increases. Our problem-orientation is primarily influenced by family socialisation and negative orientation is mostly defined by one's mother's (or tender's) negative orientation and problem-solving behaviour (e.g., Nezu et al., 2004). It is also proven that one's negative orientation during childhood and adolescence may bear long-term effects on academic-professional success and the quality of one's social connections, and may play a significant role in the development of the feeling of hopelessness, stress and depression (e.g., Eskin, 2013; Frauenknecht \& Black, 2010).

A number of theoretical models have been developed to analyse social problemsolving (e.g., D’Zurilla et al., 2002; Crick \& Dodge, 1979; Frauenknecht \& Black, 2010). According to D'Zurilla et al. (2002), social problems induce a complex (cognitive-emotionalbehavioural) and mostly conscious process, the aim of which is the solution of the problem as well as the reduction and cancellation of uncomfortable feelings and thoughts caused by the problem. This process is regarded as social problem-solving and is divided into two sub processes (orientation and solution). The orientation includes one's sensitivity towards the problem, dedication to solving it as well as self-efficacy which can be positive (adaptive) or negative (maladaptive, dysfunctional). During the solution, the problem is defined, alternative modes of solution are sought and they are evaluated considering the possible outcomes. Then 
it is decided which one to realise which is followed by implementation (solution). D'Zurilla et al. (2002) distinguished three general problem-solving styles (rationality, impulsivity, avoidance) which may combine in one problem situation as well based on the characteristics of the situation, problem and the ones involved. Our problem-solving style becomes more and more situation- and person-specific with age, and our problem-solving is more and more defined by our past experiences (in the form of habits, examples, often used techniques) which influence our problem-solving as unconscious processes during both the orientation and solution phase (Frauenknecht \& Black, 2010).

In the orientation phase, our thinking works based on a positive or negative motivation-emotion basis (D'Zurilla \& Nezu, 2007). The central item to this is self-efficacy (Bandura, 1994, p. 71), 'one's belief in his/her ability to attain a certain level of achievement and this influences such events that bear an impact on others' lives,' or, in other words, one's belief that in a problem situation we can reach the desired effect with our actions, and we can influence our decisions, our ambitions towards the solution as well as our efforts regarding the given action. Frauenknecht and Black (2010) believe that self-efficacy means the verification of one's intentions, aims and personal possibilities within a social problem. Maydeu-Olivares and D'Zurilla (1996) distinguished three dimensions of negative orientation (negative self-efficacy; pessimistic approach to the problem; low level of frustration tolerance) and five dimensions of positive orientation (the interpretation of the problem as a challenge; one's faith in positive outcomes; positive self-efficacy; positive thoughts related to the time and energy invested into the solution; one's belief in the need for a solution and that it cannot be avoided).

D'Zurilla and Maydeu-Olivares (1995) as well as D'Zurilla et al. (2004) claim that questionnaires are the most appropriate measurements to comprehensively detail social problem-solving while film and story analyses are less appropriate due to strong emotional 
involvement which lowers reliability. One part of the questionnaires enables the measurement of the complete process of problem-solving (orientation and solution) while the other part enables the measurement of a given sub process (e.g., emotion-based modes of solution, avoidance). Problem-Solving Inventory (PSI, Heppner, 1988), Social Problem-Solving Inventory-Revised (SPSI-R, D’Zurilla et al., 2002) and Social Problem-Solving Inventory for Adolescents (SPSI-A, Frauenknecht \& Black, 2010) all have good reliability indexes, are internationally well-known and are often utilised among adolescents. The Negative Problem Orientation Questionnaire (NPOQ, originally in French: Gosselin, Ladouceur, \& Pelletier, 2005; English version: Robichaud \& Dugas, 2005) is one of the most often used questionnaires which is capable of measuring adults and negative problem orientation within one factor.

PSI measures negative and positive orientation with only factor (Problem-solving confidence) where the item that expresses negative orientation (the feeling of uncertainty in a problem situation) is listed as an inverted one among the items that contain positive orientation (trusts oneself; can solve the problem; the individuals sees him/herself as a persistent and creative problem-solver). Positive and negative orientation can be measured by separate factors (Positive problem orientation, Negative problem orientation) in SPSI-R. The items of negative orientation express a cognitive-emotional set while the items of positive orientation primarily express a cognitive approach set; thus, the statements in the questionnaire related to positive orientation touch up on beliefs and the ones related to negative orientation touch up on emotions. The items of negative orientation express that the problem itself, the decision-making process, the attempt and the possible failure all entail negative emotions (dread, fear, nervousness, uncertainty, redundancy). The statements of positive orientation contain that the individual sees a social problem as a challenge; he/she faces the problem; begins thinking through how to solve it right away; he/she is persistent to 
find the best solution; does not give up if he/she cannot solve it at first.

The factor that expresses orientation in SPSI-A (Problem orientation) contains three sub factors: thoughts, emotions and behaviour. The frequency of some of the forms of avoidance (e.g. postponement, neglecting, waiting) can be measured with the items of the avoidance factor. The emotions and thoughts factors both contain items that express positive and negative orientation. The ones that bear negative contents, similarly to SPSI-R, express a feeling of discomfort at the beginning of, during and at the end of the problem-solving process in contrast to the ones that bear positive contents (the need to solve the problem, the possibility of a positive outcome, hoping for a successful outcome).

The statements in the NPOQ focus on the cognitive elements of negative orientation (e.g. detected threat, lack of self-efficacy, negative consequences). To measure the convergent and discriminative validity of the NPOQ, the adult version of SPSI-R was used and, based on the results, the Negative problem orientation factor of SPSI-R and the NPOQ measure similar constructs (even when the NPOQ measures the cognitive components of negative problem orientation to a bigger and the emotional character of problem-solving to a lesser degree).

Based on the research carried out with SPSI-R by Chang et al. (2004), negative orientation is followed by impulsivity (emotion-based, expressing negative emotions, often hasty, rather concentrated on oneself, less empathic) or avoidance (running away from the problem, abandoning the situation, postponing the solution) to a higher degree than positive orientation which shows a strong correlation with rationality (concentrates on facts, weighing in on the alternatives, taking consequences into consideration) among adolescents and adults alike. It is less frequent that negative orientation is in a strong connection with rationality and that positive orientation is a strong connection with impulsivity or avoidance.

Between 2009 and 2016, several analyses (cross sectional, longitudinal and comparative) were carried out with SPSI-R and SPSI-A among 8-18-year-olds and university 
students (e.g., Kasik, 2015; Kasik \& Gál, 2017; Kasik \& Guti, 2015; Kasik et al., 2016).

Based on these analyses, negative orientation related to social problems and their solutions is more and more typical from age 10-11 and the frequency of positive orientation decreases. Negative orientation is the most typical among 13-15-year-olds in the age group of 10-18year-olds and its connection with avoidance strengthens from age 13-14. It was among the boys that a rare sample was observed where negative orientation is combined with a high degree of rationality and, as a third component, avoidance joins them. Based on this string of connections (negative orientation-rationality-avoidance), it may be hypothesised that negative orientation has such characteristics which are positive to the individual, and thus the process does not end (immediate avoidance with strong impulsivity) and avoidance does not follow negative orientation immediately (avoidance becomes part of a conscious, thought out decision). Based on this, we may suppose that negative problem orientation is always not dysfunctional because in certain cases, this system of connections and its manifestation in one's behaviour may also bear positive outcomes (or at least the individual hopes so) which may be a significant function of self-protection.

\section{Aims.}

In 2016, a questionnaire (NEGORI) was developed based on the theoretical models, the items expressing negative orientation from the presented and partly used questionnaires, and the system of categories of the reasons of negative orientation in order to measure negative orientation. With the data collected in 2016, an exploratory factor analysis (EFA) was carried out and the connection between the factors was examined along with age and gender related differences. With the data collected in 2017, a confirmatory factor analysis (CFA) was carried out as well as structural equation model (SEM) to show the causal dependences between the 
(endogenous and exogenous) dimensions. The aim of the current study was - with the EFA and CFA - to develop a multi-factor questionnaire which enables a more detailed examination of interpersonal problems and negative orientation towards their solution. Furthermore, age and gender differences were revealed in this sample as well and the results of the also completed SPSI-R (D'Zurilla et al., 2002) were used to examine the convergent and discriminative validity of the NEGORI.

\section{Sample and data collection.}

The first data collection took place in 2016, the second in 2017 (with a repeated data collection). The first data collection was carried out in autumn 2016 among 12-, 15- and 18year-old $\left(\mathrm{M}_{12}=12.13 \mathrm{SD}_{12}=.78 ; \mathrm{M}_{15}=15.07 \mathrm{SD}_{15}=.45 ; \mathrm{M}_{18}=18.11 \mathrm{SD}_{18}=.51\right)$ primary and secondary school students. 952 students were involved in the research $\left(\mathrm{N}_{12}=310, \mathrm{~N}_{15}=\right.$ $301, \mathrm{~N}_{18}=341 ; \mathrm{N}_{\text {girls: }} 12,15,18=56,54,58 \%$ ). Based on the recorded background variables, the distribution of mothers' highest educational qualification (Hungarian system: 8 years of primary school, vocational school certificate, technical college certificate, grammar school certificate, college/university degree $)$ in the three age groups was $\operatorname{similar}\left(\chi^{2}=21.19 \mathrm{p}=.25\right)$.

The other data collection was carried out on a sample of 835 students $\left(\mathrm{N}_{12}=290, \mathrm{~N}_{15}=\right.$ $\left.270, \mathrm{~N}_{18}=275\right)$ in spring $2017\left(\mathrm{M}_{12}=12.05 \mathrm{SD}_{12}=.76 ; \mathrm{M}_{15}=15.12 \mathrm{SD}_{15}=.41 ; \mathrm{M}_{18}=17.98\right.$ $\mathrm{SD}_{18}=.62 ; \mathrm{N}_{\text {girls: }} 12,15,18=55,56,57 \%$ ). In the case of this one, another data collection was carried out after two weeks. Based on mothers' highest educational qualification the three subsamples do not differ significantly from one another either $\left(\chi^{2}=20.23 p=.29\right)$.

The data collection was carried with the headmasters' and parents' consent in all cases, who were informed about its content and aim. The data collection took the time of one lesson in all cases. 


\section{Statistical analysis.}

The EFA was carried out with the SPSS 24 programme and for the CFA, Mplus 6.11 was used (Muthén \& Muthén, 2010). PAF method was used in the EFA with 'promax' (Kappa= 4) rotation (factor load $\geq .4$ ). To determine the usability of the data in the factor analysis, the Bartlett test and the Kaiser-Meyer-Olkin (KMO) indicator was used.

In the CFA, weighted least squares, mean and variance-adjusted (WLSMV) approximation was used as well as Theta-parameterisation (Muthén \& Muthén, 2010). The fitness of the model was examined with the Tucker-Lewis Index (TLI) - relative fit index, with one non-centrality-based fit index, the comparative fit index (CFI) and two absolute fit indexes (RMSEA, SRMR). Based on the literature, the appropriacy of the model is indicated by values above .9 and .95 for CFI and TLI, and values lower than .06 or .08 for RMSEA (Byrne \& Stewart, 2006).

Cronbach- $\alpha$ was chosen as the indicator of the reliability of internal consistency which, according to Nunnally (1978), is acceptable from a value of .7. Age related differences were examined with ANOVA, gender differences were examined by independent sample ttest. Pearson's r was used in the correlation analysis.

\section{Measurements.}

The convergent and discriminative examination of the NEGORI was done with SPSI-R (D’Zurilla et al., 2002). The questionnaire consists of 25 items and the statements are grouped into five factors: Positive orientation, Negative orientation, Rationality, Impulsivity, Avoidance (for their contents, see Introduction). The statements have to be evaluated on a 
five-fold scale $(1=$ Absolutely not true for me $-5=$ Absolutely true for me $)$. Based on national research, the factor structure of the questionnaire is completely the same as the original English version's factor structure and measures well among 11-18-year-olds. Its reliability index (Cronbach- $\alpha$ ) is above .76 at all ages (for more detail about the national cross-sectional and longitudinal studies see: Kasik, 2014; Kasik et al., 2010).

\section{Pilot study: the development process of the NEGORI (Negative Orientation Questionnaire).}

Even though we have collected a lot of information about the characteristics of negative problem orientation in adolescence, the used tools (SPSI-R, SPSI-A) were able to analyse only the mentioned dimensions and if we are to carry out a correlation analysis with other psychological factors, those conclusions only relate to these fields. A half a year-long development programme (Gál, 2017; Kasik \& Gál, 2016) carried out among adolescents (1213-year-olds) also showed that negative orientation towards social problems and their solutions show more in the background than that the results of previous questionnaires tell us and these are strongly connected with other psychological and social factors (e.g. high degree of anxiety, often feeling excluded, insufficient adaptation to one's peers).

In order to find out the background of negative orientation from the adolescents themselves as well, a pilot data collection was carried out with the involvement of some of the students who participated in our earlier longitudinal research carried out with SPSI-R (Kasik, $2014,2015,2016)$. In the longitudinal study $(\mathrm{N}=180)$, the problem-solving of the 12 -yearsold students at the beginning was analysed through three years; it was in the second year that we were able to shed more light on why the then-13-year-olds $(\mathrm{N}=52)$ would not like to or do not want to solve their interpersonal problems. Those students were involved in the pilot 
research who reached a high (4.2 or higher out of 5) average in the negative orientation factor in both years. They had to answer two questions: (1) How do you usually feel: would you like to solve your social problems? (2) If not, why not? With the second question, we were able to reveal the problem and the reasons for not dealing with its solution.

Based on the theory of reason attribution (e.g., Heider, 2003), the answers contained both external (situational) and internal (personal) reasons. Blaming the other person, the lack of the other person's initiation and the effect of the model people are, for example, external reasons. The fear of the negative outcome of solving the problem, the positive consequences that brings relief or negative self-efficacy (projecting the unsuccessful solution) can be regarded as internal reasons. Two of the categories completely matched with the contents of two items of negative problem orientation in SPSI-R (the individual does not deal with the problem because of the bad feeling and negative self-efficacy caused by failure). At the same time, several categories were defined which the questionnaire-based research did not provide information about in terms of their contents. These include habit/pattern (e.g. 'Because I saw my parents doing this.'), waiting/initiation (e.g. 'Because I am waiting for the other one to initiate.'), the source of the problem (e.g. 'Because it is not my fault') and not dealing with problem-solving as being something positive (e.g. 'Because this is how things will be good for me.').

Based on the categories of the pilot research, our group of psychologists and assessment and evaluation researchers created eight theoretical factors and attributed 5-6 statements to these. In addition to this, 49 12-year-olds, 51 15-year-olds and 48 18-year-olds were asked to formulate 5-5 statements for each theoretical factor created (students were given detailed information about their contents). This was needed in order to expand the information received from the adolescents in the pilot research because only students with high negative orientation values were asked in that. 
The statements written down by the experts and the students were finalised by the task force. The final questionnaire contains 40 statements (which are the completions for the sentence that begins as follows: 'I do not want to solve my problem because...'): (1) failure/fear of shame (5 items, e.g. '...this way I cannot fail in trying to solve it.'), (2) negative self-efficacy (5 items, e.g. '...I am certain that I cannot solve it.'), (3) negative outcome (5 items, e.g. ' ...I am afraid that it might have negative consequences.'), (4) positive outcome (5 items, e.g. ' $\ldots$ this is what makes me calm.'), (5) the source of the problem (5 items, e.g. ' ...it is not my fault.'), (6) habit, pattern (5 items, e.g. ' ...my mother does not deal with her problems either.'), (7) redundancy (5 items, e.g. ' ...there is no point in solving it.'), (8) waiting (5 items, e.g. ' ...I am waiting for the problem to solve itself.'). The statements are to be evaluated on a Likert scale $(0=$ Not typical of me at all $-4=$ Absolutely typical of me $)$.

\section{Results.}

\section{The structure of NEGORI - the results of the EFA (2016).}

An EFA was carried with the data from the 2016 data collection. Based on the analysis, the same six factors were distinguished at all three ages: (1) Fending off the problem (4 items), (2) Negative consequences (4 items), (3) Negative self-efficacy (3 items), (4) Positive consequences (3 items), (5) Habit, pattern (3 items), (6) Waiting (3 items). The validity and reliability indexes of the factors and the NEGORI (in the case of the whole sample and the age groups) are summarised in Table 1.

Table 1 
The statements of Fending off the problem express that the individual would not like to deal with his/her problems because he/she thinks that he/she did not cause them (e.g. ‘...because I am usually not responsible.'). The statements of Negative consequences express that with regard to problem-solving, the individual takes short and long-term negative personal and social consequences into consideration which causes negative feelings in him/her (e.g. ' ...I am afraid that it will end badly.'). The statements of Negative self-efficacy express the individual's belief that he/she cannot or is not able to solve his/her problems, finds him/herself incapable of it and thus has a negative attitude towards the problem and its solution (e.g. '...I am certainly unable to solve the problem.'). In the case of the statements of Positive consequences, the individual thinks that not dealing with the problem has positive consequences for him/her and brings a relief to him/her: he/she will not be nervous or sad (e.g. '...this is what makes me calm.'). In light of the statements of Habit, pattern, it is the individual's environment that provides the pattern not to deal with his/her problems (e.g.

'...we do not usually do this at home.'). In terms of the statements of Waiting, the individual expects his/her problems to solve themselves; therefore, he/she is passive, does not see him/herself as an active problem-solver (e.g. ' ... it will somehow solve itself.').

\section{The system of the connections between the NEGORI factors (2016).}

The intercorrelation values of the NEGORI factors as per age are summarised in Tables 2 and 3. In all three age groups, the connections are significant, positive and between .17 and .61. At all three ages, the values between Negative self-efficacy and Negative consequence are the highest (above $r=.50$ ). Among 12-year-olds, the connection between Fending off the problem and Positive consequence is the weakest and among 15- and 18-year-olds it is the connection between Fending off the problem and Negative self-efficacy (below $r=.20$ ). 
Table 2

Table 3

\section{Age and gender differences (2016).}

Age related differences were identified in the case of all six factors of the NEGORI from which we can only deduce changes through the cross-sectional study (Table 4). The average scores of age samples differ significantly in the case of Negative self-efficacy and show a tendency of decrease with the advancement of age $(\{12\}>\{15\}>\{18\})$; the scores of the Positive consequence also show a decrease $(\{12\}>\{15,18\})$ but in the case of this factor, the two older age groups do not distinguish significantly. In contrast, Negative consequence and Fending off the problem are together more significant among 15- and 18-year-olds than 12year-olds $(\{12\}<\{15,18\})$, and 18-year-olds also attained a higher score on the factors of Habit, pattern and Waiting $(\{12,15\}<\{18\})$. Standard deviation values are lower in the case of Fending off the problem and Negative consequence at all three ages and, in the case of Waiting, they are lower among 12- and 15-year-olds than in the case of other factors and at other ages which points to a lesser degree of individual variation within the given age group.

Table 4

There is no significant difference between 12-year-old boys' and girls' results in any of the factors. Among the 15-year-olds, boys gained a higher average score in the case of Fending off the problem (boys: $\mathrm{M}=3.25 \mathrm{SD}=.23$; girls: $\mathrm{M}=2.96 \mathrm{SD}=.34 \mathrm{t}=2.77 \mathrm{p}=$ .006 ) and Habit, pattern (boys: $\mathrm{M}=1.35 \mathrm{SD}=.39$; girls: $\mathrm{M}=.83 \mathrm{SD}=.28 \mathrm{t}=2.51 \mathrm{p}=.011$ ) while girls' average score was higher in the case of Negative consequence (boys: $M=3.15$ $\mathrm{SD}=.20$; girls: $\mathrm{M}=3.65 \mathrm{SD}=.21 \mathrm{t}=-2.24 \mathrm{p}=.026$ ). Among the 18 -year-olds, it was also the boys who gained higher scores in Negative self-efficacy (boys: $\mathrm{M}=1.95 \mathrm{SD}=.27$; girls: 
$\mathrm{M}=1.41 \mathrm{SD}=.23 \mathrm{t}=1.67 \mathrm{p}=.045)$ and Fending off the problem (boys: $\mathrm{M}=3.70 \mathrm{SD}=$ 1.03; girls: $\mathrm{M}=3.12 \mathrm{SD}=1.22 \mathrm{t}=2.51 \mathrm{p}=.039)$.

\section{Results of the CFA and SEM (2017).}

The factor structure of NEGORI was tested on the data collected in 2017 with CFA. The fitness of the model is satisfactory; the CFA carried out with the six factors separated during the 2016 EFA also show satisfactory fitness indexes: $12: \chi^{2}=289.98 \mathrm{p}<.001 \mathrm{df}=174 \chi^{2 / d f}=$ $1.67 \mathrm{CFI}=.92 \mathrm{TLI}=.90 \mathrm{RMSEA}=.05(\mathrm{p}=.25) \mathrm{SRMR}=.06 ; 15: \chi^{2}=237.12 \mathrm{p}<.001 \mathrm{df}=$ $174 \chi^{2 /} \mathrm{df}=1.36 \mathrm{CFI}=.97 \mathrm{TLI}=.96 \mathrm{RMSEA}=.04(\mathrm{p}=.98) \mathrm{SRMR}=.05 ; 18: \chi^{2}=285.65 \mathrm{p}$ $<.001 \mathrm{df}=174 \chi^{2 /} \mathrm{df}=1.64 \mathrm{CFI}=.95 \mathrm{TLI}=.94 \mathrm{RMSEA}=.04(\mathrm{p}=.88)$ SRMR $=.05 ;$ whole sample: $\chi^{2}=386.4 \mathrm{p}<.001 \mathrm{df}=174 \chi^{2 /} \mathrm{df}=2.22 \mathrm{CFI}=.96 \mathrm{TLI}=.95 \mathrm{RMSEA}=.04(\mathrm{p}=$ 1.00) $\mathrm{SRMR}=.04$.

SEM was used to describe the system of connections between the factors and theoretical model of the effects the variables have on one another (Figure 1) with the data from the second collection. Based on the research that has been carried out so far and the intercorrelational coefficients revealed in this research, it was hypothesised that the central latent variable of the model was Negative self-efficacy, which directly effects all factors, and that Fending off the problem, Negative consequence and Positive consequence directly affect the Habit, pattern and Waiting variables.

Figure 1

The fitness of the theoretical model is satisfactory: $12: \chi^{2}=319.49 \mathrm{p}<.001 \mathrm{df}=176$

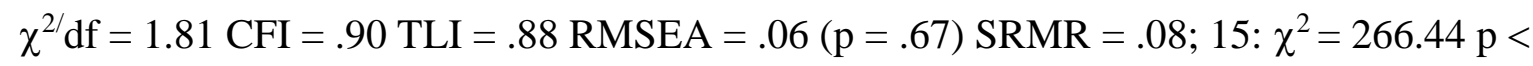
$.001 \mathrm{df}=176 \chi^{2 /} \mathrm{df}=1.51 \mathrm{CFI}=.95 \mathrm{TLI}=.94 \mathrm{RMSEA}=.04(\mathrm{p}=.87)$ SRMR $=.07 ; 18: \chi^{2}=$ 
$325.71 \mathrm{p}<.001 \mathrm{df}=176 \chi^{2 /} \mathrm{df}=1.84 \mathrm{CFI}=.93 \mathrm{TLI}=.92 \mathrm{RMSEA}=.05(\mathrm{p}=.48) \mathrm{SRMR}=$ .05 ; whole sample: $\chi^{2}=466.06 \mathrm{p}<.001 \mathrm{df}=174 \chi^{2 /} \mathrm{df}=2.68 \mathrm{CFI}=.94 \mathrm{TLI}=.93 \mathrm{RMSEA}=$ $.04(\mathrm{p}=.98) \mathrm{SRMR}=.06$. At the same time, more imputed relationships were not significant; therefore, those were deleted. The fitness thus received is satisfactory, it is consistent with the theoretical model in whole sample (Figure 2) and in all age subsamples (Figures 3-5): 12: $\chi^{2}$ $=272.54 \mathrm{p}<.001 \mathrm{df}=132 \chi^{2 /} \mathrm{df}=2.06 \mathrm{CFI}=.92 \mathrm{TLI}=.90 \mathrm{RMSEA}=.06(\mathrm{p}=.14) \mathrm{SRMR}=$ $.08 ; 15: \chi^{2}=266.44 \mathrm{p}<.001 \mathrm{df}=176 \chi^{2 / \mathrm{df}}=1.51 \mathrm{CFI}=.95 \mathrm{TLI}=.94 \mathrm{RMSEA}=.04(\mathrm{p}=$ .87) $\mathrm{SRMR}=.07 ; 18: \chi^{2}=327.80 \mathrm{p}<.001 \mathrm{df}=177 \chi^{2 / \mathrm{df}}=1.85 \mathrm{CFI}=.93 \mathrm{TLI}=.92 \mathrm{RMSEA}$ $=.05(\mathrm{p}=.48) \mathrm{SRMR}=.05 ;$ whole sample: $\chi^{2}=466.06 \mathrm{p}<.001 \mathrm{df}=176 \chi^{2 / \mathrm{df}}=2.64 \mathrm{CFI}=$ $.94 \mathrm{TLI}=.93 \mathrm{RMSEA}=.04(\mathrm{p}=.98) \mathrm{SRMR}=.06$.

Figure 2

Figure 3

Figure 4

Figure 5

In accordance with the theoretical model, in the case of the whole sample, the Negative consequence has not significant effect on Habit, pattern and Waiting. The Negative selfefficacy directly effects the latent variables of Fending off the problem, Negative consequence, Positive consequence and Waiting in all three age samples (Figures 2-4); Positive consequence and Habit, pattern were predicted by the Fending off the problem. This system of prediction is supplemented by the direct effect of (1) Fending off the problem on Waiting, Positive consequence and Waiting, (2) Negative self-efficacy on Habit, pattern in the sample of 15-year-olds. In the case of 15- and 18-year-olds, the models are nearly identical, the values of the estimations do not differ greatly from one another (in the two models). 
Negative consequence is only predicted by Negative self-efficacy in all three age samples and, in contrast to the theoretical model, this latent variable has not significant effect on other latent variables.

\section{The connection between the data from the second and the repeated collection (2017).}

Upon the second, 2017 data collection, a repeated measurement was also carried out (due to the fact that the results from the second and the repeated measurement are identical, the latter will not be disclosed in detail). The connection between the data was analysed by correlation analysis (Table 5). The correlation values in the case of the factors are between .51 and .72; in the case of the whole questionnaire (in age order), they are .63, .67 and .62.

\section{Table 5}

\section{Age and gender differences (2017).}

The analyses carried out on the data collected in 2016 and 2017 showed age related differences which were completely the same (and because the data from the and the repeated collection are the same, the latter will not be disclosed this time either). Based on 2016 and 2017 data, Negative self-efficacy and Positive consequence both point to a tendency of decrease while the tendency of increase with the advancement of age can be hypothesised in the case of the factors of Negative consequence, Fending off the problem, Habit, pattern and Waiting. The differences revealed in 2016 were also identified, and in the 2017 sample, 15year-old boys gained the highest score not only in the case of Fending off the problem and Habit, pattern but Waiting too (boys: $\mathrm{M}=1.39 \mathrm{SD}=.35$; girls: $\mathrm{M}=.90 \mathrm{SD}=.34 \mathrm{t}=2.45 \mathrm{p}=$ $.015)$. 


\section{Convergent and discriminative validity - the connection between NEGORI and SPSI-R}

(2017).

The analysis of the convergent and discriminative validity of NEGORI was carried out on the data from the second collection (2017) for which we used SPSI-R (Positive orientation, Negative orientation, Rationality, Impulsivity, Avoidance). In the SPSI-R factors, students gained a similar score in all three age groups that our earlier cross sectional and their confirmatory longitudinal studies identified. The gradual decrease of positive orientation, the increase of negative orientation, avoidance and rationality, and the constantly high value of impulsivity is characteristic between the ages of 12 and 18 (see Kasik, 2014, 2015). Table 6 shows the results of the correlation analysis as per age.

Table 6

Positive orientation is a negative significant connection with Negative self-efficacy and Waiting in all three age groups (Table 6). Negative orientation is in a positive connection with all NEGORI factors and in almost all age groups; of these, the values in connection with the factors of Fending off the problem and Negative self-efficacy are the highest among 12and 15-year-olds. The factor of Avoidance bears no significant connection with any NEGORI factor among 12-year-olds; however, it does with 15- and 18-year-olds. The connection between the factors of Avoidance, Waiting and Negative self-efficacy are the strongest among 15-year-olds. Rationality and Impulsivity is a significant connection with only the factors of Habit, pattern and Waiting (the former is negative, the latter is positive) among 15- and 18year-olds.

\section{Discussion.}


Development of the NEGORI. The Negative orientation factor of SPSI-R contains statements that express negative self-efficacy, little belief in the solution, that the solution is something unnecessary, little estimation of the consequences, the negative connection between the solution and the future, and the difficult nature of dealing with the frustration caused by the solution. Based on earlier research carried out with the questionnaire, the gradual increase of negative orientation between age 12 and 18 is typical. In the pilot study, areas related to Negative orientation showed up individually or as a subcategory based on the categorisation of 13-year-old students' responses; however, several other categories were also separated with contents that earlier questionnaire-based research did not provide information of. These include problem-solving based on patterns (accounts for behaviour with the behaviour of a model person), the absence of dealing with the problem regarded as something positive (not dealing with the problem will be good for him/her) and waiting for the other person to initiate the solution of the problem (he/she is not to blame, thus he/she is not the one who should initiate the solution). In addition to little self-efficacy, little belief in the solution of the problem and feeling that the solution is unnecessary, there seemed to be the low level or lack of taking responsibility, the fear of unsuccessful solution and escaping the shame caused by the unsuccessful solution in the background (Kasik, 2016) - all this was confirmed by the results of the pre- and post-measurement results of the six-month development programme and the experience gained during the occupations as well (Gál, 2017).

The results of the pilot research unequivocally supported the assumption that in order to understand negative problem orientation, fields other than the ones covered by the questionnaires should also be taken into consideration. The categories of reasons revealed in the pilot largely contributed to the development of the NEGORI. Based on the analysis of the factor structure of the original, 40-statement questionnaire, the final, 21-item NEGORI has good reliability indexes in all three age groups. The six factors partially cover the fields that 
measure negative orientation in PSI, SPSI-R and SPSI-A, and most categories of the pilot measurement. The results of the CFA confirmed the six-factor model in all three ages. The 'I do not want to solve my problem because...' statement beginnings most likely account for the fact that the connection between the NEGORI factors are positive in all age groups. Based on the analysis of the convergent and discriminative validity, the Negative orientation factor of SPSI-R is in a positive connection with all NEGORI factors at almost all ages, which was confirmed by other tools that measure negative orientation as well (e.g., Robichaud \& Dugas, 2005). One of the reasons for this is the content overlap of the items of Negative orientation and the NEGORI factors.

Results of the SEM. The results of the SEM largely confirmed what had previously been theorised about the connection between the variables in the whole sample and in all age groups. The system of connections shows that negative self-efficacy can be regarded as the central component of negative problem orientation even 12-year-olds, which affects the initiation or their rejection of the solution of the problems, the fear of negative consequences and that individual attributes positive consequences to not beginning the problem-solving. All this, directly or indirectly, shapes and forms problem-solving habits, experiences give patterns, and we wait for the problem to either solve itself or for the initiation of the other person and for him/her to solve it without our participation.

Age-related characteristics. Upon examining the age-related characteristics, the same differences were identified in both samples; therefore, the 2017 data confirms the 2016 data in a way. The results gained from the NEGORI factors give more detail about the age-related characteristics gained with SPSI-R (e.g., Kasik, 2014, 2015) because based on the NEGORI, the age-related variations of negative self-efficacy related to the problems and their solutions show a tendency of decrease $(\{12\}>\{15\}>\{18\})$. However, taking negative consequences into consideration bears a more powerful presence and one's degree of belief in positive 
consequences decreases. Supposedly, these together feed negative self-efficacy. Negative orientation as a pattern, and waiting and fending off the problem increase with age and the manifestation of these are caused by effects of socialisation: family members', teachers' and peers' negative orientation affects students' orientation of this sort. Fending off the problem ('It's not my fault, therefore I do not have to do anything') can be analysed when strongly linked to taking responsibility, but it poses the lack of interpreting and seeing through the problem and the relations within the problem. Based on the data, waiting is in correlation with avoidance as a problem-solving style, which was also confirmed by the result of the validity test. Based on Scheier et al. (1986) as well as Chang and Sanna's (2001) research, the orientation and behaviour of those in one's direct environment (family, peers) significantly shapes high negative self-efficacy. Pessimistic adolescents take few possible solutions into account, more often than not they decide based on their feelings, the result of which is usually the avoidance of solving the problem. This system of connections is also reflected in the results of the validity test: the Habit, pattern and the Waiting factors have a negative connection with the rational problem-solving style, and have a positive one with impulsivity and avoidance. The increasingly definitive nature of these two reasons support Frauenknecht and Black's (2010) research results that claim that problem-solving, with its orientation and solution processes alike, is more and more defined by past experiences in the form of habits and patterns with the advancement of age.

Gender differences. No significant difference was identified in the case of any of the factors among 12-year-old girls and boys during either the 2016 or the 2017 research. In earlier longitudinal research carried out with SPSI-R, it was also found that significant differences in the measured fields can be identified from age 13-14 (Kasik, 2015). Negative orientation measured with one factor is more typical of girls, according to previous studies. The NEGORI gives a more detailed picture in this sense as well, which is also different 
because in the Fending off the problem and Habit, pattern factor boys' values are higher (in the Waiting factor too in the 2017 research) while girls' values are higher in the case of Negative consequence. In the pilot research, fear of negative consequences was recurring exclusively in girls' responses which reflects the research data that claims that it is more typical of them that others' opinion (and the requirements formulated within it) defines the mode of the solution of problems and conflicts more, and that their approach is more emotionbased (e.g., Grusec \& Davidov, 2007; Ladd, 2005). However, it is in contrast with the results of the pilot research that it was not girls but boys who gained a higher score in the Habit, pattern factor; based on this, following a pattern is more typical of them. According to Frauenknecht and Black (2010), it is mainly the effect of one's family which is difficult to change (if the individual feels the need to do so at all) because the everyday negative experiences which are lived through together feed negative attitude and the correlation values also display that negative orientation itself, and with it avoidance, are interpreted as beneficial. This can viewed as a viable short term solution (e.g. the tension caused by the problem decreases), but it may be dysfunctional in the long run because problems crop up later and they usually have a detrimental effect on social relations (Laplanche \& Pontalis, 1994).

Among 18-year-olds, it boys' values again which are higher in the case of Negative self-efficacy and Fending off the problem. Gender difference is the opposite of the data from the pilot research in the case of Fending off the problem; however, it must be taken into consideration that in the pilot it was students themselves who formulated the reasons of their negative orientation (and they were 13 years old at the time) while during the completion of the questionnaire, students had to evaluate given statements. Based on the pilot, it is more typical of girls to see the other person as the source of the problem, they wait for them to initiate the solution which is in connection with taking responsibility retrospectively and by 
rationally weighing in on the future (Szabó et al., 2015); the detailed revelation of this will definitely be needed in the future.

Limitation and future. Even though the NEGORI can be considered to be apt to shed light on fending off the problem, negative and positive consequence, negative self-efficacy, habit and pattern, and waiting as reasons for negative orientation, several further studies are needed in order to refine the questionnaire, on the one hand and to analyse the data in more detail, on the other hand. Upon completion, the students could think of problems, problematic situations related to anyone; therefore, it will be useful to create the person-specific version of the NEGORI in the future (as in the case of SPSI-R, Kasik, 2015) which requires the changing of the statements in the Habit, pattern factor because those contain family, peer and teacher model people. It will also be important to shed light on the connection between the NEGORI and other fields, such as anxiety, general self-efficacy, coping, self-evaluation and the aforementioned responsibility-taking. The results of these correlation analyses will also contribute to making school development programmes for children and adolescents that focus on problem-solving even better and to be able to concentrate on the solution-defining orientation as well by taking more personal characteristics into consideration in addition to problem-solving styles.

\section{References.}

Bandura, A. (1994). Self-efficacy. In V. S. Ramachaudran (Ed.), Encyclopedia of human behavior (pp. 71-81). New York: Academic Press.

Byrne, B. M. \& Stewart, S. M. (2006). The MACS approach to testing for multigroup invariance of a second-order structure: A walk through the process. Structural Equation Modeling, 13, 287-321. 
Chang, E. C. \& Sanna, L. J. (2001). Optimism, pessimism, and positive and negative affectivity in middle-aged adults: A test of a cognitive-affective model of psychological adjustment. Psychology and Aging, 16, 524-531.

Crick, N. R. \& Dodge, K. A. (1994). A review and reformulation of social informationprocessing mechanisms in children's social adjustment. Psychological Bulletin, 115, 74-101.

D'Zurilla, T. J. \& Nezu, A. M. (2007). Problem-solving therapy: A positive approach to clinical Intervention. New York: Spring Publishing Company.

D’Zurilla, T. J., Nezu, A., \& Maydeu-Olivares, A. (2002). Social Problem-Solving InventoryRevised (SPSI-R): Technical Manual. North Tonawanda, New York: Multi-Health Systems.

D’Zurilla, T. J., Nezu, A., \& Maydeu-Olivares, A. (2004). Social Problem Solving: Theory and Assessment. In E. C. Chang, T. J. D’Zurilla, \& L. J. Sanna (2004), Social problem solving. Theory, research, and training (pp. 5-28). Washington, DC: American Psychological Association.

Eskin, M. (2013). Social Problem Solving Therapy in the Clinical Practice. Elsevier. Turkey. Frauenknecht, M. \& Black, D. R. (2010). Is it social problem solving or decision making? Implications for health education. American Journal of Health Education, 41(2), 112123.

Gosselin, P., Ladouceur, R., \& Pelletier, O. (2005). Evaluation of an individual's attitude toward daily life problems: the Negative Problem Orientation Questionnaire. Journal de Thérapie Comportementale et Cognitive, 15(4), 141-153.

Gál, Z. \& Kasik, L. (2017). Egy serdülők körében végzett szociálisprobléma-megoldást fejlesztő tréning és tanulságai. In D. Molnár, É. \& Vígh, T. (Eds.), PÉK 2017 [CEA 
2017] XV. Pedagógiai Értékelési Konferencia. Szeged, 2017. 04. 06.-2017. 04. 08.

SZTE BTK Neveléstudományi Doktori Iskola, Szeged. p. 140

Grusec, J. E. \& Davidov, M. (2007). Socialization in the family: The roles of parents. In J.

Grusec \& P. Hastings (Eds.), Handbook of socialization (pp. 284-308). New York: Guildford Press.

Heider, F. (2003). A személyközi viszonyok pszichológiája. Budapest: Osiris Kiadó.

Heppner, P. P. (1988). The Problem Solving Inventory (PSI): Manual. Palo Alto, CA:

Consulting Psychologists Press.

Kasik, L. (2014). Development of social problem solving - A longitudinal study (2009-2011) in a Hungarian context. European Journal of Developmental Psychology, 12(2), 142158.

Kasik, L. (2015). Személyközi problémák és megoldásuk. Budapest: Gondolat Kiadó.

Kasik, L. (2016). „Nem szeretném megoldani” A kortársi problémák megoldásával kapcsolatos negatív orientáció vizsgálata serdülök körében. Alkalmazott Pszichológia, $16(2), 37-51$.

Kasik, L. \& Gál, Z. (2016). „Nem szeretném megoldani” A kortársi problémák megoldásával kapcsolatos negatív orientáció jellemzői serdülők körében. In D. Molnár, É. \& Vígh, T. (Eds.), PÉK 2017 [CEA 2017] XV. Pedagógiai Értékelési Konferencia. Szeged, 2017. 04. 06.-2017. 04. 08. SZTE BTK Neveléstudományi Doktori Iskola, Szeged. p. 138

Kasik, L., Gáspár, CS., Guti, K., \& Zsolnai, A. (2016). Relationship between Social Problem Solving, Anxiety and Empathy among Adolescents in Hungarian Context. In K. Newton (Ed.), Problem-Solving: Strategies, Challenges and Outcomes (pp. 177-196). New York: NOVA Science Publishers, Inc.

Kasik, L. \& Guti, K. (2015). A kortársi versengés és problémamegoldás jellemzői serdülők körében. Magyar Pszichológiai Szemle, 70(1), 179-195. 
Kasik, L., Nagy, Á., \& Fűzy, A. (2010). Szociálisprobléma-megoldás kérdőiv. Kézirat. SZTE BTK Neveléstudományi Intézet, Szeged.

Ladd, G. W. (2005). Children's Peer Relations and Social Competence: A Century of Progress. New Haven/London: Yale University Press.

Laplanche, J. \& Pontalis, J. B. (1994). A pszichoanalizis szótára. Budapest: Akadémia Kiadó. Maydeu-Olivares, A. \& D'Zurilla, T. J. (1996). A factor-analytic study of the Social ProblemSolving Inventory: An integration of the theory and data. Cognitive Therapy and Research, 20, 115-133.

Muthén, L. K. \& Muthén, B. O. (2010). Mplus user's guide. Los Angeles, CA.

Nezu, A. M., Wilkins, V. M., \& Nezu, C. M. (2004). Social problem solving, stress, and negative affect. In E. C. Chang, T. J. D'Zurilla, \& L. J. Sanna (Eds.), Social problem solving (pp. 49-65). Washington, DC: American Psychological Association.

Nunnally, J. C. (1978). Psychometric theory. New York: McGraw-Hill.

Robichaud, M. \& Dugas, J. (2005). Negative problem orientation (Part I): Psychometric properties of a new measure. Behaviour Research and Therapy, 43(3), 391-401.

Scheier, M. F., Weintraub, J. K., \& Carver, C. S. (1986). Coping with sress. Divergent strategies of optimists and pessimists. Journal of Personality and Social Psychology, $51,1257-1264$.

Strough, J. \& Keener, E. (2013). Interpersonal problem solving across the life span. In P. Verhaeghen, P. \& C. Hertzog (Eds.), The Oxford handbook of emotion, social cognition, and everyday problem solving during adulthood. Oxford University Press, The Oxford Library of Psychology Series.

Szabó, É., Zsadányi, ZS. \& Szabó Hangya, L. (2015). Ki szeret iskolába járni? Az iskolai kötődés, a motiváció, az énhatékonyság és a tanulmányifelelősség-vállalás vizsgálata. Iskolakultúra, 25(10), 5-20. 


\section{Table, figure}

Table 1

The results of the EFA and reliability $(N=952)$

\begin{tabular}{lccccc}
\hline \multicolumn{1}{c}{ Factor/NEGORI } & $\begin{array}{c}\text { Number } \\
\text { of items }\end{array}$ & $\begin{array}{c}\text { Whole } \\
\text { sample }\end{array}$ & $\begin{array}{c}\text { Cronbach- } \alpha \\
\text { 12-year- } \\
\text { olds }\end{array}$ & $\begin{array}{c}15 \text {-year- } \\
\text { olds }\end{array}$ & $\begin{array}{c}18 \text {-year- } \\
\text { olds }\end{array}$ \\
\hline Fending off the problem & 4 & .85 & .80 & .84 & .89 \\
Negative consequences & 4 & .86 & .84 & .88 & .85 \\
Negative self-efficacy & 4 & .84 & .87 & .85 & .78 \\
Positive consequences & 3 & .68 & .69 & .70 & .71 \\
Habit, pattern & 3 & .69 & .66 & .69 & .70 \\
Waiting & 3 & .77 & .71 & .79 & .78 \\
NEGORI & 21 & .78 & .88 & .90 & .88 \\
\hline KMO & & .90 & .88 & .89 & .87 \\
Bartlett & & 7026.86 & 2015.28 & 2615.01 & 2683.53 \\
df & & 210 & 210 & 210 & 210 \\
p & & .00 & .00 & .00 & .00 \\
Variance $(\%)$ & & 57.66 & 68.11 & 70.22 & 65.84 \\
\hline
\end{tabular}

Table 2

The correlation of the factors (lower part: 12-year-olds, $N=310$; upper part: 15-year-olds, $N=301 ; p<0.001$ in all cases)

\begin{tabular}{lcccccc}
\hline \multicolumn{1}{c}{ Factor } & FP & NC & NS & PC & HP & W \\
\hline Fending off the problem (FP) & - & .25 & .19 & .36 & .37 & .39 \\
Negative consequence (NC) & .25 & - & .61 & .33 & .23 & .30 \\
Negative self-efficacy (NS) & .20 & .53 & - & .34 & .31 & .38 \\
Positive consequence (PC) & .19 & .43 & .42 & - & .43 & .46 \\
Habit, pattern (HP) & .25 & .33 & .25 & .29 & - & .41 \\
Waiting (W) & .21 & .46 & .53 & .40 & .39 & - \\
\hline
\end{tabular}

Table 3

The correlation of the factors (18-year-olds, $N=341 ; p<0.001$ in all cases)

\begin{tabular}{lcccccc}
\hline \multicolumn{1}{c}{ Factor } & FP & NC & NS & PC & HP & W \\
\hline Fending off the problem (FP) & - & & & & & \\
Negative consequence (NC) & .26 & - & & & & \\
Negative self-efficacy (NS) & .17 & .58 & - & & & \\
Positive consequence (PC) & .38 & .37 & .34 & - & & \\
Habit, pattern (HP) & .45 & .28 & .32 & .35 & - & \\
Waiting (W) & .41 & .25 & .26 & .39 & .32 & - \\
\hline
\end{tabular}


Table 4

Age related differences as per factor ( $M=$ mean; $S D=$ standard deviation; $A N O V A ; N=952)$

\begin{tabular}{lcccc}
\hline \multicolumn{1}{c}{ Factor } & $\begin{array}{c}\text { 12-year-olds } \\
\mathrm{M}(\mathrm{SD})\end{array}$ & $\begin{array}{c}\text { 15-year-olds } \\
\mathrm{M}(\mathrm{SD})\end{array}$ & $\begin{array}{c}\text { 18-year-olds } \\
\mathrm{M}(\mathrm{SD})\end{array}$ & $\begin{array}{c}\text { ANOVA } \\
\mathrm{F}(\mathrm{p})\end{array}$ \\
\hline Fending off the problem & $2.65(.34)$ & $3.08(.55)$ & $3.38(.44)$ & $21.01(.000)$ \\
Negative consequence & $3.05(.35)$ & $3.55(.23)$ & $3.65(.19)$ & $3.05(.035)$ \\
Negative self-efficacy & $2.81(1.11)$ & $2.19(.88)$ & $1.67(1.20)$ & $11.78(.000)$ \\
Positive consequence & $2.53(1.02)$ & $1.67(.82)$ & $1.77(.72)$ & $12.92(.000)$ \\
Habit, pattern & $1.30(.93)$ & $1.09(1.03)$ & $1.60(.77)$ & $4.29(.014)$ \\
Waiting & $1.54(.54)$ & $1.84(.44)$ & $2.12(.97)$ & $2.89(.041)$ \\
\hline
\end{tabular}

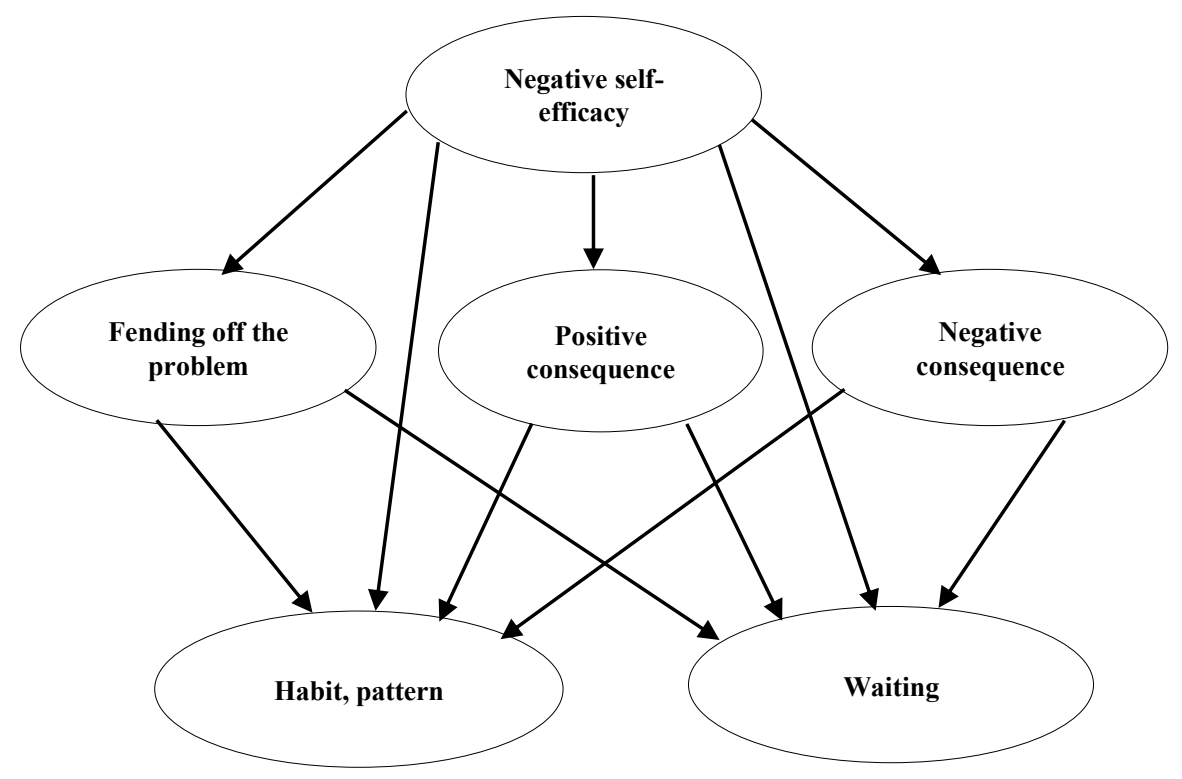

Figure 1

The theoretical model of the connection of the variables 


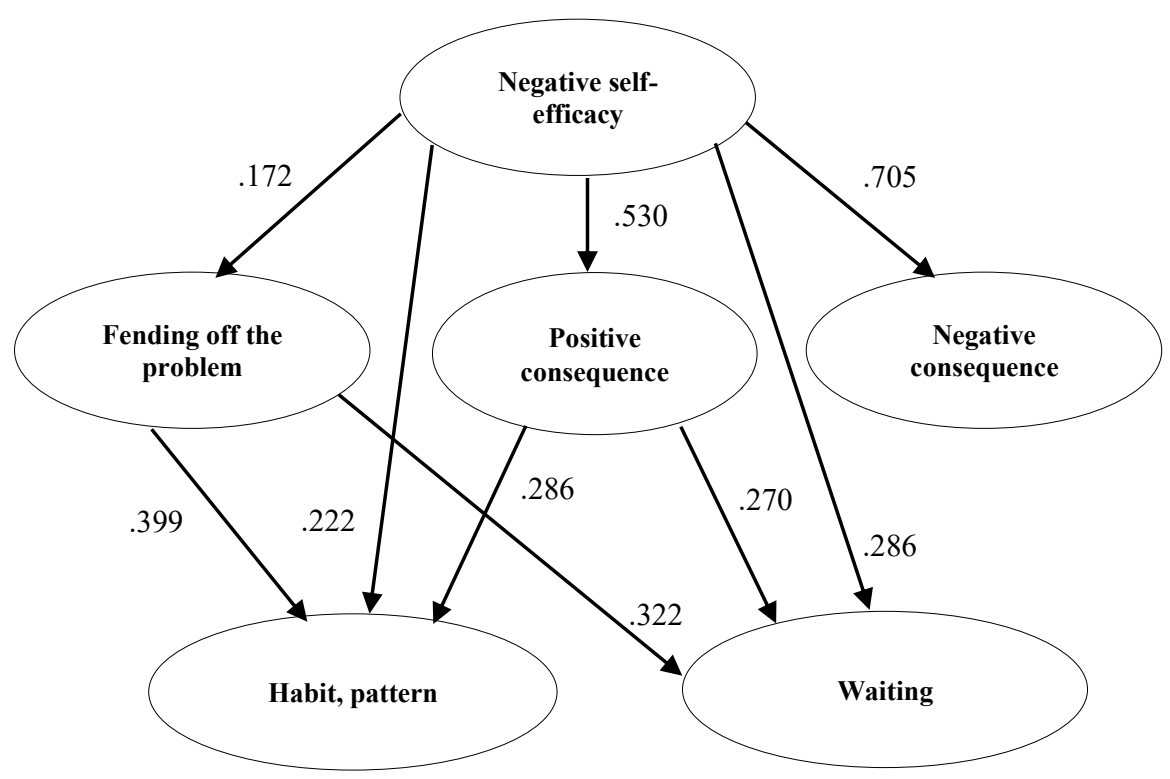

Figure 2

The results of the SEM (whole sample, $N=835$ )

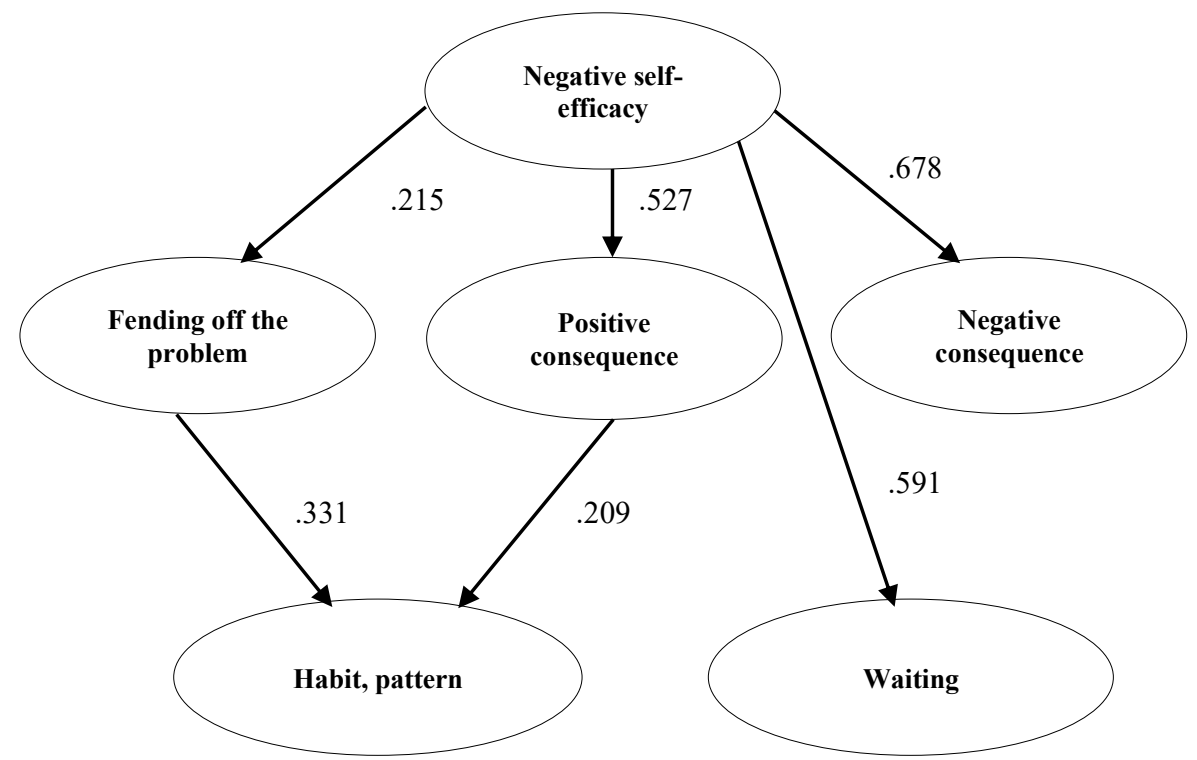

Figure 3

The results of the SEM(12-year-olds, $N=290)$ 


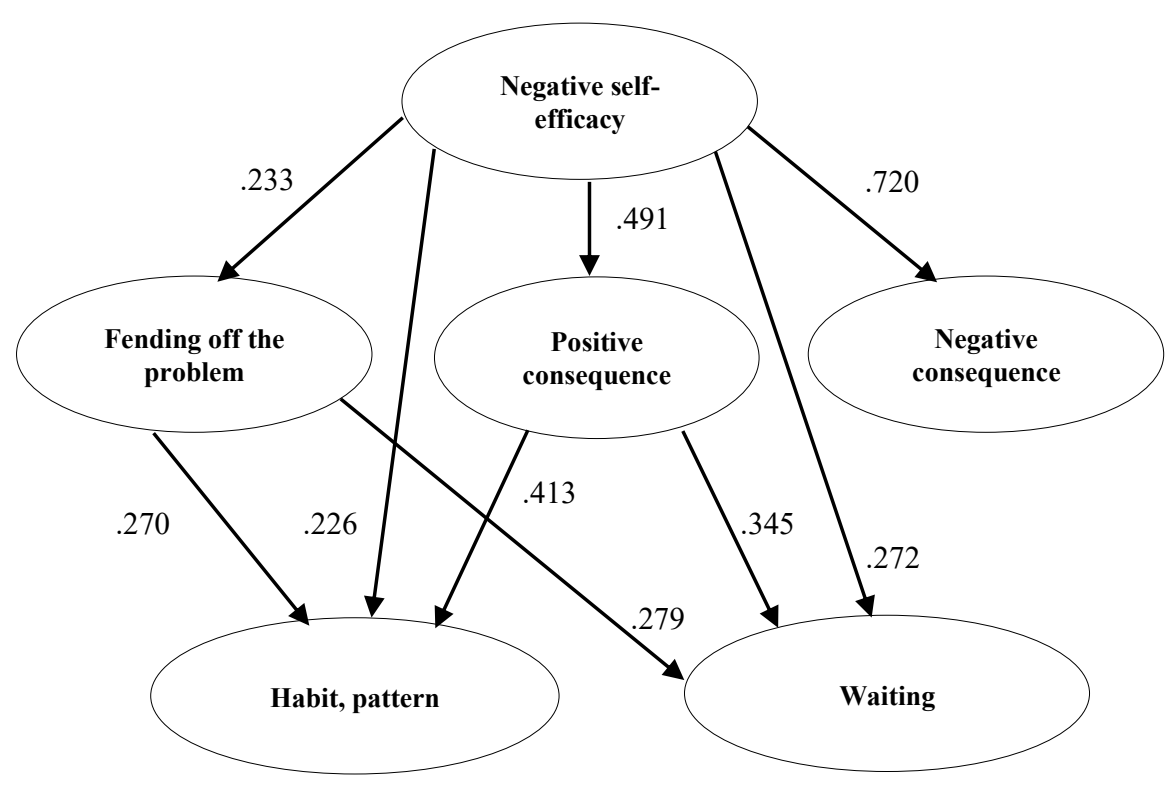

Figure 4

The results of the SEM (15-year-olds, $N=270)$

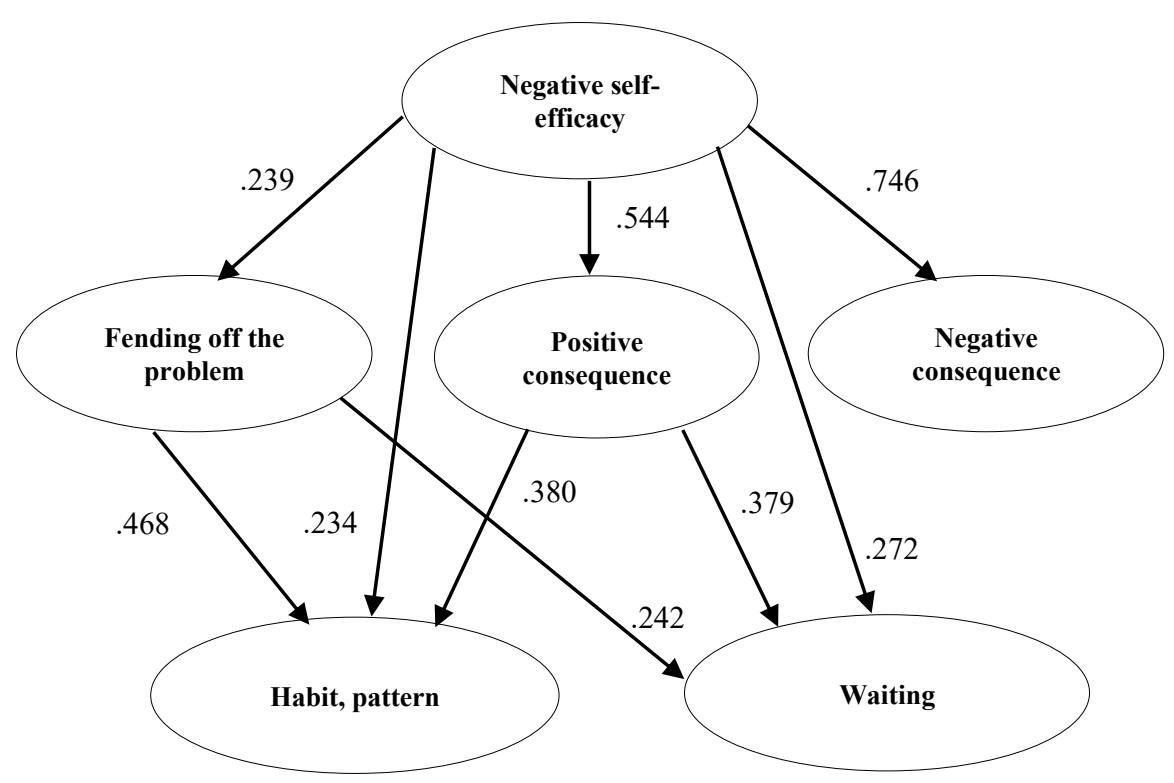

Figure 5

The results of the SEM (18-year-olds, $N=275$ )

29 
Table 5

The correlations between the first and the repeated measurement in 2017 ( $N=835, p<.05$ in all cases)

\begin{tabular}{lcccc}
\hline \multicolumn{1}{c}{ Factor/NEGORI } & $\begin{array}{c}\text { Whole } \\
\text { sample }\end{array}$ & $\begin{array}{c}\text { 12-year- } \\
\text { olds }\end{array}$ & $\begin{array}{c}\text { 15-year- } \\
\text { olds }\end{array}$ & $\begin{array}{c}\text { 18-year- } \\
\text { olds }\end{array}$ \\
\hline Fending off the problem & .64 & .61 & .71 & .63 \\
Negative consequence & .62 & .54 & .60 & .68 \\
Negative self-efficacy & .54 & .51 & .55 & .61 \\
Positive consequence & .57 & .55 & .54 & .51 \\
Habit, pattern & .63 & .61 & .64 & .61 \\
Waiting & .66 & .67 & .60 & .72 \\
\hline NEGORI & .61 & .63 & .67 & .62 \\
\hline
\end{tabular}

Table 6

The connection between the factors of NEGORI and SPSI-R $(N=835$, Pearson $r ; p<.01)$

\begin{tabular}{lcccccc}
\hline \multicolumn{1}{c}{ Factor } & $\begin{array}{c}\text { Sub- } \\
\text { sample }\end{array}$ & PO & NO & R & I & A \\
\hline \multirow{3}{*}{ Fending off the problem } & 12 & n.s. & .35 & n.s. & n.s. & n.s. \\
& 15 & n.s. & .48 & n.s. & n.s. & .31 \\
& 18 & n.s. & .29 & n.s. & n.s. & .17 \\
\hline \multirow{2}{*}{ Negative consequence } & 12 & n.s. & n.s. & n.s. & n.s. & n.s. \\
& 15 & n.s. & .20 & n.s. & n.s. & .16 \\
& 18 & n.s. & .16 & n.s. & n.s. & .17 \\
Negative self-efficacy & 12 & -.13 & .35 & n.s. & n.s. & n.s. \\
& 15 & -.22 & .55 & n.s. & n.s. & .43 \\
Positive consequence & 18 & -.15 & .28 & n.s. & n.s. & .22 \\
& 12 & n.s. & .21 & n.s. & n.s. & n.s. \\
& 15 & n.s. & .33 & n.s. & n.s. & .31 \\
Habit, pattern & 18 & n.s. & .20 & n.s. & n.s. & .23 \\
\hline \multirow{3}{*}{ Waiting } & 12 & n.s. & n.s. & n.s. & n.s. & n.s. \\
& 15 & n.s. & .26 & -.16 & .19 & .29 \\
& 18 & n.s. & .25 & -.18 & .21 & .22 \\
\hline Note. PO=Positive & 12 & -.18 & .29 & n.s. & n.s. & n.s. \\
& 15 & -.19 & .25 & -.15 & .21 & .52 \\
\hline
\end{tabular}

Note. $\mathrm{PO}=$ Positive orientation, $\mathrm{NO}=$ Negative orientation, $\mathrm{R}=$ Rationality, $\mathrm{I}=\mathrm{Impulsivity}, \mathrm{A}=\mathrm{Avoidance}$. 